\title{
High cut-off membrane for in-vivo dialysis of free plasma hemoglobin in a patient with massive hemolysis
}

\author{
David Cucchiari ${ }^{1 *}$ D, Enric Reverter², Miquel Blasco ${ }^{1}$, Alicia Molina-Andujar ${ }^{1}$, Adriá Carpio², Miquel Sanz², \\ Angels Escorsell2, Javier Fernández ${ }^{2}$ and Esteban Poch ${ }^{1}$
}

\begin{abstract}
Background: The possibility of clearing Cell-free Plasma Hemoglobin (CPH) from human plasma may appear attractive, especially when considering the noxious effects that $\mathrm{CPH}$ has on the immune function and the renal damage caused by its filtration. The existence of the so-called High Cut-Off (HCO) filters, possessing pores as big as $60 \mathrm{kDa}$, could potentially allow the clearance of the a $\beta$ dimers $(31.3 \mathrm{kDa})$, the form in which the a2 $\beta 2$ hemoglobin tetramers $(62.6 \mathrm{kDa})$ physiologically dissociate in plasma. We present herein the first reported case in which such an attempt was made.

Case presentation: The patient was a 51-year-old man with hemolytic crisis due to glucose-6-phosphate dehydrogenase deficiency, further complicated by pigment-induced nephropathy. He underwent a 48-h CWHD session, in which a HCO filter was used. The Sieving Coefficient (SC) for CPH was initially 0.08 and decreased to 0.02 after $24 \mathrm{~h}$. This unexpected low SC was due to the initial high concentration of $\mathrm{CPH}(4.24 \mathrm{~g} / \mathrm{L})$. At such concentrations, the a2 $\beta 2$ tetramer poorly dissociates into the a $\beta$ dimer; but increases exponentially at concentrations lower than $1 \mathrm{~g} / \mathrm{L}$.

Conclusions: Clearance of CPH through a HCO filter is technically feasible but its performance markedly relies on the initial concentration of $\mathrm{CPH}$. Critically ill patients with smoldering hemolysis, as it happens during septic shock or ECMO treatment, may benefit the most from the use of this membrane in order to clear $\mathrm{CPH}$.
\end{abstract}

Keywords: Free hemoglobin, High-cut off filter, Acute kidney injury, Sepsis, Continuous renal replacement therapy

\section{Background}

The presence of Cell-free Plasma Hemoglobin (CPH) in human plasma derives from the erythrocytes breakdown and depletion of haptoglobin, the plasmatic protein devoted to $\mathrm{CPH}$ scavenging. This usually occurs in massive hemolysis, in the context of which haptoglobin-binding capacity is exhausted and $\mathrm{CPH}$ is filtered by glomeruli. The glomerular filtration of hemoglobin can lead to pigmented-cast nephropathy, a fearsome complication that may require urgent hemodialysis [1]. Apart from the cases of massive hemolysis, $\mathrm{CPH}$ can also be found in acutely ill patients with compromised liver function

\footnotetext{
* Correspondence: david.cucchiari@gmail.com

${ }^{1}$ Nephrology and Renal Transplant Unit, Hospital Clínic, Carrer Villaroel 170, 08036 Barcelona, Spain

Full list of author information is available at the end of the article
}

because of a decreased production of haptoglobin as well as in patients undergoing extracorporeal treatments like hemodialysis and ECMO. In these cases, the $\mathrm{CPH}$ concentration is just slightly higher with respect to the physiological levels and is unable to cause significant kidney damage. However, $\mathrm{CPH}$ presents some toxic effects even at low levels, since it alters the pathogen-induced inflammatory response. Animal models have demonstrated that lipopolysaccharide (LPS)-induced release of TNF- $\alpha$ is increased after exposure to $\mathrm{CPH}[2,3]$. Moreover, a clinical study clearly demonstrated that $\mathrm{CPH}$ is a strong predictor of mortality in septic patients [4]. Therefore, the possibility to dialyze $\mathrm{CPH}$ in septic patients may represent an intriguing topic of research in the next future. Recently, an in-vitro proof-of-concept model demonstrated that a High-Cut Off (HCO) 
hemofilter with pores of $60 \mathrm{kDa}$ diameter is able to dialyze the $\alpha \beta$ hemoglobin dimer, whose molecular weight is $31.3 \mathrm{kDa}$ [5]. The dimer is that part of the hemoglobin molecule that is actually filtered by the glomerulus and that eventually causes pigmented-cast nephropathy [6]. The tetramer composed by two $\alpha$ and two $\beta$ subunits, which is the physiological carrier of oxygen within erythrocytes, weighs instead $62.6 \mathrm{kDa}$; this is scarcely filtered by the glomerulus and by $\mathrm{HCO}$ filters. Thus, clearance of $\mathrm{CPH}$ depends on the dissociation degree of $\mathrm{Hb}$ tetramers into dimers. To the best of our knowledge, we report the first case of a patient with massive hemolysis and Acute Kidney Injury (AKI) treated with a HCO filter that allowed us to verify the possibility to clear $\mathrm{CPH}$ in-vivo from human plasma.

\section{Case presentation}

A 51-year-old man presented to the emergency department with fever, abdominal pain and jaundice. Past and recent medical history were unremarkable and the patient did not report any recent trip, risky sexual behaviour, parenteral drug intake or ingestion of potentially contaminated food. The physical examination revealed right hypochondrium and epigastric tenderness and no signs of peritonitis. Lab tests showed Aspartate AminoTransferase (AST) 3560 UI/L, Alanine AminoTransferase (ALT) 4513 $\mathrm{UI} / \mathrm{L}$, hyperbilirubinemia (total $16 \mathrm{mg} / \mathrm{dL}$ ), alkaline phosphatase, GGT 90/418 UI/L, PT 50\%, normal pancreatic enzymes and normal renal function. Abdominal ultrasound showed no alterations.

Twenty-four hours after the admission, liver function rapidly declined, with PT $40 \%$ and maximum total bilirubin of $47 \mathrm{mg} / \mathrm{dL}$. In parallel, blood test showed an elevation of LDH, haptoglobin consumption, reticulocytosis and AKI stage 3 with creatinine of $4 \mathrm{mg} / \mathrm{dL}$ and a peripheral blood smear suggestive of hemolysis. Urinalysis was positive for bilirubin and hemoglobin, while the urinary sediment discarded the presence of red blood cells. Serological tests were positive for IgM Hepatitis A Virus (HAV). In addition, a previously unknown complete glucose-6-phosphate dehydrogenase deficiency was detected.

On the basis of these findings a diagnosis of acute hepatitis A infection complicated with massive hemolysis due to glucose-6-phosfate dehydrogenase deficiency was done. Hemolysis was probably triggered by fitomenadione administration and its diagnosis was partially masked by high bilirubin levels due to the severe hepatitis. AKI was interpreted as the result of pigmented-cast nephropathy. The haemolytic crisis was initially managed with 2 sessions of plasma exchange. However, considering the need of dialysis and the presence of $\mathrm{CPH}$, continuous renal replacement treatment with a $\mathrm{HCO}$ filter (Septex ${ }^{\mathrm{m}}, 1.1 \mathrm{~m}^{2}$, Gambro-Baxter, Hechingen, Germany; Fig. 1) in CVVHD modality was started. In order to measure the $\mathrm{CPH}$

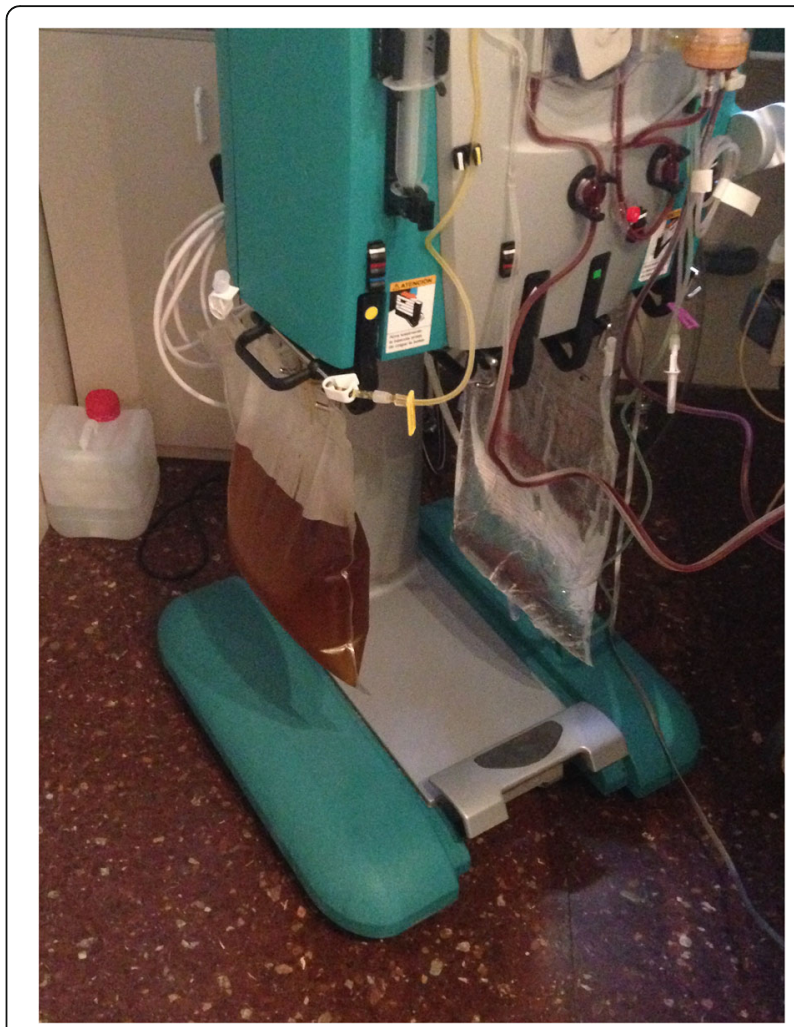

Fig. 1 Effluent bag during the first day of therapy. The brownish hue depends on the presence of high bilirubin levels (yellow) along with the filtered $\mathrm{CPH}$ (red)

clearance, plasma was collected in EDTA tubes from arterial, venous and dialysate ports of the CRRT circuit and $\mathrm{CPH}$ was measured with Drabkin-based spectrophotometric analysis at $540 \mathrm{~nm}$. The Sieving coefficient (SC) was calculated as $C_{D} /\left[C_{\text {In }}+C_{\text {Out }} / 2\right]$ where $C_{D}, C_{\text {In }}$ and $C_{\text {Out }}$ represent $\mathrm{CPH}$ concentration at the dialysate, blood inlet and blood outlet side. $\mathrm{CPH}$ clearance was calculated as $\left\{\mathrm{C}_{\mathrm{D}} /\left[\mathrm{C}_{\mathrm{In}}+\right.\right.$ $\left.\left.\mathrm{C}_{\text {Out }} /(2)\right]\right\} \mathrm{Q}_{\mathrm{e}}$, where $\mathrm{Q}_{\mathrm{e}}$ is the effluent flow. This filter was used for $48 \mathrm{~h}$, observing a $\mathrm{CPH}$ value of $4,24 \mathrm{~g} / \mathrm{L}$ at the beginning and of $3,72 \mathrm{~g} / \mathrm{L}$ at the end of the treatment. The calculated $\mathrm{SC}$ for $\mathrm{CPH}$ was 0.08 at treatment start, later decreasing to 0.02 after $24 \mathrm{~h}$. The calculated clearance of $\mathrm{CPH}$ declined as well, from $2,87 \mathrm{ml} / \mathrm{min}$ on the first day to $0,76 \mathrm{ml} / \mathrm{min}$ after $24 \mathrm{~h}$ (Table 1 for treatment data and $\mathrm{CPH}$ clearance profile, Table 2 for common laboratory data before and after CVVHD treatment).

After this treatment, as the patient was still oliguric, seven sessions more of intermittent hemodialysis were performed. Eventually, 4 weeks after admission urine output ensued and the patient's renal function started to recover. At the time of discharge, total bilirubin was $3.4 \mathrm{mg} / \mathrm{dL}$ and creatinine $2.8 \mathrm{mg} / \mathrm{dL}$. Finally, 3 months after discharge the patient presented normal renal and hepatic function. 
Table 1 Treatment data and CPH concentrations 30', $24 \mathrm{~h}$ and $48 \mathrm{~h}$ after CRRT start

\begin{tabular}{llll}
\hline & $30 \mathrm{~min}$ & $24 \mathrm{~h}$ & $48 \mathrm{~h}$ \\
\hline$C_{\text {In }}(\mathrm{g} / \mathrm{L})$ & 4,24 & 4,33 & 3,72 \\
$C_{\text {Out }}(\mathrm{g} / \mathrm{L})$ & 4,23 & 4,19 & 3,66 \\
$C_{D}(\mathrm{~g} / \mathrm{L})$ & 0,37 & 0,1 & 0,07 \\
Sieving Coefficient & 0,087 & 0,023 & 0,018 \\
Clearance $(\mathrm{ml} / \mathrm{min})$ & 2,87 & 0,76 & 0,62 \\
$\mathrm{Q}_{\mathrm{b}}(\mathrm{m} / \mathrm{min})$ & 250 & 250 & 250 \\
$\mathrm{Q}_{\mathrm{d}}(\mathrm{m} / \mathrm{min})$ & 33 & 33 & 33 \\
$\mathrm{Q}_{\mathrm{e}}(\mathrm{ml} / \mathrm{Kg} / \mathrm{h})$ & 28,2 & 29 & 29 \\
UF $(\mathrm{ml} / \mathrm{h})$ & 0 & 50 & 50 \\
\hline
\end{tabular}

$C_{\text {In }} \mathrm{CPH}$ concentration at the arterial side, $\mathrm{C}_{\mathrm{Out}} \mathrm{CPH}$ concentration at the venous side, $C_{D} \mathrm{CPH}$ concentration at dialysate side, $Q_{b}$ blood flow, $Q_{d}$ dialysate flow, $Q_{e}$ effluent flow, UF UltraFiltration rate

\section{Discussion and conclusions}

To the best of our knowledge, we report the first case of in-vivo $\mathrm{CPH}$ clearance by means of HCO-based CVVHD treatment. $\mathrm{HCO}$ filters have been designed to improve clearance of middle-sized molecules that were not previously cleared by normal filters, such as pro- and anti-inflammatory cytokines [7-10]. The possibility to clear $\mathrm{CPH}$ has been recently examined in an in-vitro model, in which the authors demonstrated the efficacy of the same HCO filter that we used, with a SC for $\mathrm{CPH}$ of 0.35 and a clearance of approximately $22 \mathrm{ml} / \mathrm{min}$ [5]. However, in our case the initial SC was of only 0.08 , decreasing to 0.02 in the following $24 \mathrm{~h}$, presumably due to the phenomenon of protein-coating. $\mathrm{CPH}$ clearance was reduced as well, with values below $3 \mathrm{ml} / \mathrm{min}$ initially: albeit not negative, this

Table 2 Main laboratory values before and after 48-h long treatment with the HCO membrane

\begin{tabular}{lll}
\hline & Before HCO-CWHD & After HCO-CWHD \\
\hline Creatinine $(\mathrm{mg} / \mathrm{dL})$ & 6.48 & 3.55 \\
AST/ALT $(\mathrm{UI} / \mathrm{L})$ & $196 / 314$ & $106 / 208$ \\
Alkaline Phosphatase $(\mathrm{UI} / \mathrm{L})$ & 66 & 89 \\
Gamma-GT (UI/L) & 51 & 111 \\
Direct Bilirubine $(\mathrm{mg} / \mathrm{dL})$ & 31.2 & 24.2 \\
Indirect Bilirubine $(\mathrm{mg} / \mathrm{dL})$ & 4.8 & 4 \\
Haptoglobine $(\mathrm{g} / \mathrm{L})$ & Undetectable & 0.54 \\
C-Reactive Protein $(\mathrm{mg} / \mathrm{dL})$ & 6.48 & 5.89 \\
Na/K (mEg/L) & $140 / 4.4$ & $137 / 4$ \\
Albumin $(\mathrm{g} / \mathrm{L})$ & 28 & 28 \\
Total protein $(\mathrm{g} / \mathrm{L})$ & 41 & 50 \\
Hemoglobin $(\mathrm{g} / \mathrm{L})$ & 81 & 108 \\
Platelets $\left(\times 10^{3} / \mathrm{L}\right)$ & 192 & 177 \\
White Blood Cells $\left(\times 10^{3} / \mathrm{L}\right)$ & 13.53 & 7.29 \\
Prothrombin Time $(\%)$ & 69.7 & 59.9 \\
\hline
\end{tabular}

clearance is far from being clinically relevant. In order to explain the striking difference with the results obtained in the in-vitro model, we should consider the dissociation characteristics of the hemoglobin tetramers $(62.6 \mathrm{kDa})$ into dimers $(31.3 \mathrm{kDa})$. Indeed, the hemoglobin dimer is the part of the molecule that is cleared by the $\mathrm{HCO}$ filter under study, whose cut-off is $60 \mathrm{kDa}$. As the dissociation of tetramers into dimers is maximum at low concentrations of $\mathrm{CPH}$, the best results are obtained with $\mathrm{CPH}$ concentrations lower than $1 \mathrm{~g} / \mathrm{L}$. In the above-cited in-vitro study, indeed, the $\mathrm{CPH}$ concentration was within this range and the approximate dissociation degree at this concentration was around $40 \%$. On the other side, our patient had much higher $\mathrm{CPH}$ concentration $(4.24 \mathrm{~g} / \mathrm{L})$. At this level, the expected dissociation degree is lower than $10 \%$ [5]. Therefore, the lower SC for $\mathrm{CPH}$ observed in our case is probably due to the lesser degree of dissociation of the molecule. This point provides an important indication, since it demonstrates that those patients that would benefit the most from this treatment are those presenting $\mathrm{CPH}$ levels lower than $1 \mathrm{~g} / \mathrm{L}$. Presumably, patients with massive hemolysis and already established kidney injury are less likely to benefit from HCO-based $\mathrm{CPH}$ clearance. On the other side, critically ill patients with smoldering hemolysis and lower concentrations of $\mathrm{CPH}$ should theoretically take more advantage from it. For example, pediatric patients submitted to two different types of ECMO treatment had mean $\mathrm{CPH}$ values between 0.36 and $0.58 \mathrm{~g} / \mathrm{l}$ [11], while $\mathrm{CPH}$ values in septic patients ranged from 0.034 to $0.185 \mathrm{~g} / \mathrm{L}$ [4]. It is worthy to underline that even these low levels of $\mathrm{CPH}$ are not harmless. In a rat model, purified hemoglobin enhanced TNF- $\alpha$ synthesis in LPS-stimulated macrophages by a factor of 1.000 [2]. In another model, the administration of hemoglobin in LPS-treated mice resulted in an increase in TNF- $\alpha$ levels and mortality [3]. In humans, $\mathrm{CPH}$ was strongly associated with decreased survival in severe septic patients, even after substantial correction with already known risk factors including age, inflammatory biomarkers, Simplified Acute Physiology (SAPS-II) and Sequential Organ Failure Assessment (SOFA) scores [4].

\section{Conclusion}

In conclusion, we report the case of a patient treated with a HCO-based CRRT treatment for the clearance of $\mathrm{CPH}$. The lower than expected SC was probably due to the low dissociation of the hemoglobin tetramers into dimers, as a consequence of the high concentrations of $\mathrm{CPH}$ in our patient. Therefore, we might infer that those patients that would benefit the most from this kind of treatment are the critically ill ones with low levels of $\mathrm{CPH}$ in the context of septic shock or extracorporeal treatments like ECMO. Even at these low levels, CPH has well-documented harmful effects on the immune system. The possibility to clear $\mathrm{CPH}$ in these patients may not represent only a "cosmetic" 
intervention, but may also be beneficial in blunting the inflammatory response.

\section{Abbreviations}

AKI: Acute Kidney Injury; ALT: Alanine AminoTransferase; AST: Aspartate AminoTransferase; CRRT: Continuous Renal Replacement Therapy; CWHD: Continuous Veno-Venous HemoDialysis; ECMO: Extracorporeal Membrane Oxygenation; HAV: Hepatitis A Virus; HCO: High-Cut Off; LPS: lipopolysaccharide; SAPS-II: Simplified Acute Physiology Score II; SOFA: Sequential Organ Failure Assessment; TNF-a: Tumor Necrosis Factor Alfa

\section{Acknowledgements}

We thank Benedetta Varisco for her careful revision of the manuscript.

\section{Availability of data and materials}

Data and material supporting our findings are present in the hospital records and are available upon request after de-identification of patients' information.

\section{Authors' contributions}

$D C, E R, M B, J F$ and $E P$ contributed to the conception of the study, AMA, AC, $M S$ and $A E$ have been involved in drafting of the manuscript, JF and EP critically revised the manuscript for important intellectual content. All the authors have read and approved the final version of the manuscript, and ensure that this is the case.

\section{Ethics approval and consent to participate}

Not applicable.

\section{Consent for publication}

Written informed consent covering the publication of personal and medical information of the patient has been obtained before submission of the manuscript and is available upon request.

\section{Competing interests}

The authors declare that they have no competing interests.

\section{Publisher's Note}

Springer Nature remains neutral with regard to jurisdictional claims in published maps and institutional affiliations.

\section{Author details}

'Nephrology and Renal Transplant Unit, Hospital Clínic, Carrer Villaroel 170, 08036 Barcelona, Spain. ${ }^{2}$ Liver Intensive Care Unit, Hepatology. Hospital Clínic, Barcelona, Spain.

\section{Received: 11 April 2018 Accepted: 20 September 2018}

Published online: 04 October 2018

\section{References}

1. Shih HM, Chen YC, Pan CF, Lin HC, Wu CJ, Chen HH. Hemolysis-induced acute kidney injury following cardiac surgery: a case report and review of the literature. Hemodial Int. 2013;17(1):101-6.

2. Bloom O, Wang H, Ivanova S, Vishnubhakat JM, Ombrellino M, Tracey KJ. Hypophysectomy, high tumor necrosis factor levels, and hemoglobinemia in lethal endotoxemic shock. Shock. 1998;10(6):395-400.

3. Su D, Roth RI, Levin J. Hemoglobin infusion augments the tumor necrosis factor response to bacterial endotoxin (lipopolysaccharide) in mice. Crit Care Med. 1999;27(4):771-8.

4. Adamzik M, Hamburger T, Petrat F, Peters J, de Groot H, Hartmann M. CPH concentration in severe sepsis: methods of measurement and prediction of outcome. Crit Care. 2012;16(4):R125.

5. Hulko M, Kunz M, Yildirim M, Homeyer S, Amon O, Krause B. Cell-free plasma hemoglobin removal by dialyzers with various permeability profiles. Sci Rep. 2015;5:16367.

6. Bunn HF, Esham WT, Bull RW. The renal handling of hemoglobin. I. Glomerular filtration. J Exp Med. 1969;129(5):909-23.

7. Haase M, Bellomo R, Baldwin I, et al. Hemodialysis membrane with a highmolecular-weight cutoff and cytokine levels in sepsis complicated by acute renal failure: a phase 1 randomized trial. Am J Kidney Dis. 2007;50(2):296-304.
8. Morgera S, Klonower D, Rocktäschel J, et al. TNF-alpha elimination with high cut-off haemofilters: a feasible clinical modality for septic patients? Nephrol Dial Transplant. 2003;18(7):1361-9.

9. Morgera S, Haase M, Rocktäschel J, et al. High permeability haemofiltration improves peripheral blood mononuclear cell proliferation in septic patients with acute renal failure. Nephrol Dial Transplant. 2003;18(12):2570-6.

10. Morgera S, Haase M, Kuss T, et al. Pilot study on the effects of high cutoff hemofiltration on the need for norepinephrine in septic patients with acute renal failure. Crit Care Med. 2006;34(8):2099-104.

11. Cornelius AM, Riley JB, Schears GJ, Burkhart HM. Plasma-free hemoglobin levels in advanced vs. conventional infant and pediatric extracorporeal life support circuits. J Extra Corpor Technol. 2013;45(1):21-5.

\section{Ready to submit your research? Choose BMC and benefit from:}

- fast, convenient online submission

- thorough peer review by experienced researchers in your field

- rapid publication on acceptance

- support for research data, including large and complex data types

- gold Open Access which fosters wider collaboration and increased citations

- maximum visibility for your research: over $100 \mathrm{M}$ website views per year

At $\mathrm{BMC}$, research is always in progress.

Learn more biomedcentral.com/submissions 